\title{
Anderson's Disease: Genetic Exclusion of the Apolipoprotein-B Gene in Two Families
}

\author{
Marcia Pessah, Pascale Benlian, “ Isabel Beucler, Nathalie Loux, „ Jacques Schmitz, ${ }^{\star}$ Claudine Junien, * and Recaredo Infante \\ Institut National de la Santé et de la Recherche Médicale U.55, Hôpital Saint-Antoine, 75012 Paris; ${ }^{*}$ Institut National de la Santé et de \\ la Recherche Médicale U.73, Château de Longchamp, 75016 Paris; ${ }^{\ddagger}$ Service de Gastroentérologie Pédiatrique, Hôpital des Enfants \\ Malades, 75015 Paris, France
}

\begin{abstract}
Anderson's disease is a recessive disorder characterized by intestinal fat malabsorption, absence of postprandial chylomicrons, and reduced levels of cholesterol, triglycerides, and apoproteins B, AI, and C. We have studied two families with, respectively, three and two children with Anderson's disease. Intestinal apo-B and apo-AIV mRNAs from two Anderson's patients were normal in size but their concentration was decreased fivefold compared with controls. After DNA digestion with seven restriction enzymes, restriction fragment length polymorphisms of apo-B gene did not show conclusive information except for $\mathrm{Xba}_{1}$, which revealed a lack of cosegregation between the restriction fragment length polymorphism and the Anderson's phenotype. Linkage analysis was performed using the polymorphism of the apo-B gene 3 'minisatellite. Genomic DNA from parents and children was amplified by polymerase chain reaction using oligonucleotide primers flanking the apo-B gene 3 'hypervariable locus. In both families each child inherited different apo-B alleles from at least one parent. According to the recessive mode of transmission of the disease, our results are incompatible with the involvement of the apo-B gene. More likely a posttranslational defect or a mutation in another gene encoding a protein essential for lipoprotein assembly or secretion may be involved. (J. Clin. Invest. 1991. 87: 367-370.) Key words: apo-B • chylomicrons • genetic diseases • lipoprotein secretion
\end{abstract}

\section{Introduction}

Anderson's disease is a genetic syndrome of chronic diarrhea, fat malabsorption, malnutrition, and failure to thrive, usually diagnosed in early infancy (1). A similar condition has been described in Canadian children and named chylomicron retention disease (2). Plasma levels of LDLs and HDLs, apoproteins

This work was presented in part at the 55th Annual Meeting of the European Atherosclerosis Society, Brugge, Belgium, 17 May 1990.

Address reprint requests to Dr. Marcia Pessah, Institut National de la Santé et de la Recherche Médicale U.55, Hôpital Saint-Antoine 184, rue du Faubourg St.-Antoine, 75012 Paris, France.

Received for publication 13 July 1990 and in revised form 13 September 1990.

J. Clin. Invest.

(C) The American Society for Clinical Investigation, Inc.

$0021-9738 / 91 / 01 / 0367 / 04 \$ 2.00$

Volume 87, January 1991, 367-370
B, AI, and C, cholesterol, and phospholipids are usually below $50 \%$ of control values (3). Chylomicrons cannot be detected in the blood circulation after a fat-rich meal, despite the normal capacity of epithelial cells to absorb and esterify luminal fatty acids, indicating a failure to form and/or secrete chylomicrons into the lymphatic circulation.

The inherited inability to secrete apo-B-containing lipoproteins is exemplified by recessive abetalipoproteinemia $(\mathrm{ABL})^{1}$ and homozygous dominant hypobetalipoproteinemia (HBL). In both syndromes, affected individuals suffer from fat malabsorption, central and peripheral neuropathy, and retinal degeneration. However, in HBL, the parents obligate heterozygotes, have moderately low levels of cholesterol, triglycerides, apo-B, and apo-AI, and are usually free of clinical manifestations, whereas parents of $\mathrm{ABL}$ patients cannot be distinguished from normal subjects (4). It has been found that in two families, ABL does not cosegregate with the apo-B gene (5), while in contrast, in patients with $\mathrm{HBL}$ the disorders result from mutations in the apo-B gene (6-7).

The purpose of this study was to further investigate the molecular defect in Anderson's disease. Specifically, the linkage between the phenotype and a defect in the apo-B gene was studied by both restriction fragment length polymorphism (RFLP) and by the polymorphism of the apo-B gene 3'minisatellite consisting of a variable number of tandemly repeated short A + T-rich DNA sequence (VNTR). Our results provide the first clear genetic evidence that Anderson's disease is not due to a defect in the apo-B gene.

\section{Methods}

Description of the patients. B.S. $\left(\mathrm{I}_{2}\right)$, born in 1975 , was the first child from Algerian parents. She presented with growth retardation and diarrhea. The diagnosis of Anderson's disease was made at $3.5 \mathrm{yr}$. Her brother B.S. $\left(\mathrm{II}_{1}\right)$, born in 1985 , was admitted to the hospital for the first time at $3 \mathrm{mo}$. He presented with severe steatorrhea. $Z$ family has been described previously (3).

RNA and DNA extraction and analysis. Intestinal biopsies from the patients and normal subjects were obtained after informed consent was given. Total cellular RNA was isolated by ethanol precipitation in guanidine- $\mathrm{HCl}$ adapted to small samples (8). RNA was size fractionated by $1 \%$ agarose gel electrophoresis in the presence of formaldehyde, transferred to a Gene Screen Plus membrane (New England Nuclear,

1. Abbreviations used in this paper: $\mathrm{ABL}$, abetalipoproteinemia; $\mathrm{HBL}$, hypobetalipo-proteinemia; PCR, polymerase chain reaction; RFLP, restriction fragment length polymorphism; VNTR, variable number of tandem repeats. 
Boston, MA) by Northern blotting; and hybridized to labeled cDNA probes as described (9). For dot blots, RNA pellets were dissolved in phosphate buffer, denatured $15 \mathrm{~min}$ at $65^{\circ} \mathrm{C}$ in the presence of formaldehyde, and immediately chilled on ice. RNA was then spotted in serial dilutions on Gene Screen Plus membranes. Filters, baked at $80^{\circ} \mathrm{C}$ for 2 $\mathrm{h}$, were hybridized to cDNA probes and then autoradiographed. After laser scanning of films, mRNA levels were expressed as conventional densitometric units.

Blood from patients and control subjects was collected on 0.13 MEDTA (9:1 vol/vol). Leukocyte DNA was prepared by published methods (10). DNA Southern blotting analysis was performed using the following DNA probes: $A B F, S_{9}, A_{1}(11) ; R_{2} P_{2}(12)$ spanning the whole apo-B gene (Fig. 1). A human apolipoprotein-AIV cDNA clone ( $5^{\prime}$ AIV cDNA) of about $0.7 \mathrm{~kb}$ was used. A human $\beta$-actin cDNA clone (pHF $\beta-A_{1}$ ) isolated from a cDNA library (13) was used as positive control for the evaluation of apo-B100 and apo-AIV mRNAs. Probes were labeled by nick translation with $\left.{ }^{32} \mathrm{P}\right] \mathrm{dCTP}$ to a sp act of $\sim 2 \times 10^{8}$ $\mathrm{cpm} / \mu \mathrm{g}$.

Southern blotting and hybridization analysis of genomic DNA was performed essentially as previously described (9). $10 \mu \mathrm{g}$ of DNA was digested with restriction enzymes (XbaI, PvulI, MsPI, HindIII, HinfI, BamHI, TaqI), electrophoresed in agarose gels, and blotted into Gene Screen Plus membranes. Prehybridization and hybridization of membranes with ${ }^{32} \mathrm{P}$-labeled apo-B probes were performed as previously described (9).

To analyze the apo-B gene $3^{\prime}$ hypervariable region, the sequence of the primers was chosen flanking the targeted region $3^{\prime}$ of the apo-B gene. The DNA sequences located within the targeted region made it possible to study the apo-B VNTR by polymerase chain reaction (PCR) amplification followed by electrophoresis on $4.4 \%$ acrylamide gels. The sequence of the 5 ' oligonucleotide used to prime the PCR was 5'AACGGAGAAATTATGGAGGG 3'. The sequence of the 3' PCR primer was 5'AGGTTGTTCCTCAGGATCAA 3'. Amplification was obtained by 25 cycles of PCR in an automated thermal cycler (Perkin-Elmer Cetus, Emeryville, CA) using Thermus aquaticus DNA polymerase following the manufacturer's instructions $(14,15)$

Amplified DNA was electrophoresed on $4.4 \%$ acrylamide gels at 30 $\mathrm{mA}$ for $\mathbf{2 5} \mathrm{min}$, and visualized with ethidium bromide.

\section{Results}

The patients from two unrelated families in this report satisfied the clinical and biochemical criteria for the diagnosis of Anderson's disease. They had fat malabsorption, low levels of plasma cholesterol, apo-B, and apo-AI; normal levels of triglycerides and absence of postprandial chylomicrons and apo-B48 (results not shown). Northern blot analysis of intestinal mRNA from patients of B family revealed that apo-B and apo-AIV mRNA were normal in size but reduced to $\sim 25 \%$ of that of control values obtained by dot blots analysis. Dehybridization and rehybridization of the blots with nick-translated $\beta$-actin cDNA probe ( $\mathrm{pHF} \beta$-AI) followed by autoradiography revealed similar levels of $\beta$-actin mRNA in the enterocytes from both Anderson's patients and normal subjects (data not shown).

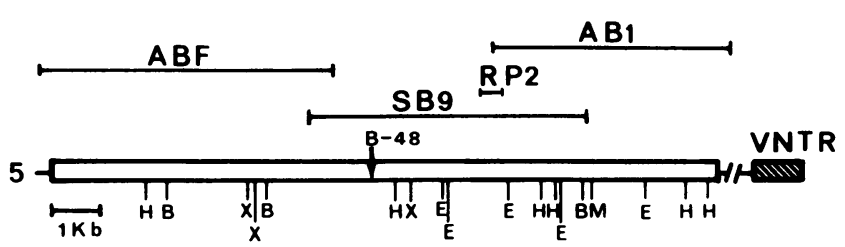

Figure 1. Restriction map of apo-B100 cDNA identifying polymorphism sites and DNA probes used in the family studies. $\mathrm{H}$, HindIII, B, BamHI, X, XbaI, E, EcoRI, M, MsPI.

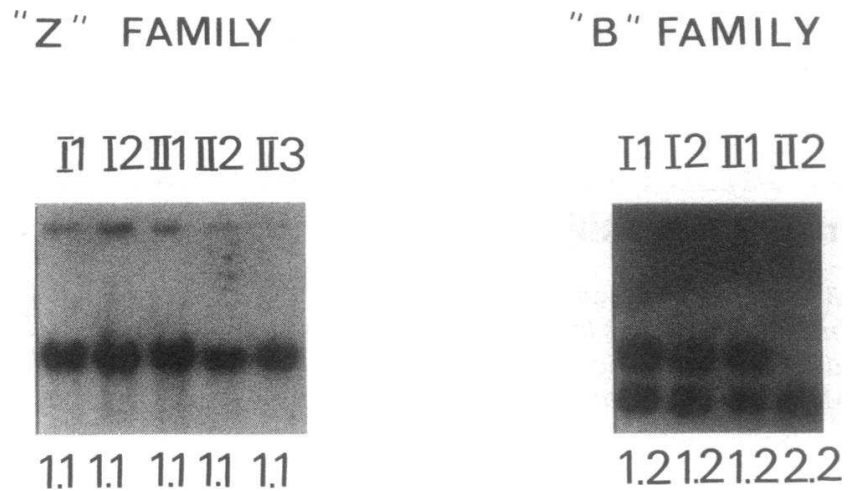

Figure 2. Southern blot analysis of genomic DNA from $\mathrm{Z}$ and $\mathrm{B}$ family. DNA was digested with the enzyme $\mathrm{Xbal}$ and hybridized with apo-B cDNA probe $\left(\mathbf{S B}_{9}\right)$.

Genomic DNA from families $B$ and $Z$ and from normal controls was digested with seven restriction enzymes and analyzed by Southern blot, as described, using apo-B cDNA probes spanning the whole gene (Fig. 1).

In $B$ and $Z$ families the RFLP with PVuII, MsPI, HindIII, Hinfl, BamHI, and TaqI were not informative (results not shown). In B family, only Xbal polymorphism contributed to genotypic information: the mother $\left(I_{1}\right)$ and father $\left(I_{2}\right)$ were heterozygous for the 8.6 and $5.5-\mathrm{kb}$ fragments; the affected girl $\left(\mathrm{II}_{2}\right)$ was homozygous for the 5.5-kb allele; and her affected brother $\left(\mathrm{II}_{1}\right)$ was heterozygous $(8.6 \mathrm{~kb}$ and $5.5-\mathrm{kb}$ alleles) (Fig. 2).

Since the RFLPs were not sufficient to clarify the linkage, we studied the VNTR polymorphism in the $3^{\prime}$ region of the apo-B gene. In family B, two different alleles were observed: VNTR 1 and 2 (Fig. 3). Father $\left(I_{1}\right)$ and mother $\left(I_{2}\right)$ had different genotypes, 1-1 and 1-2, respectively. Although both children

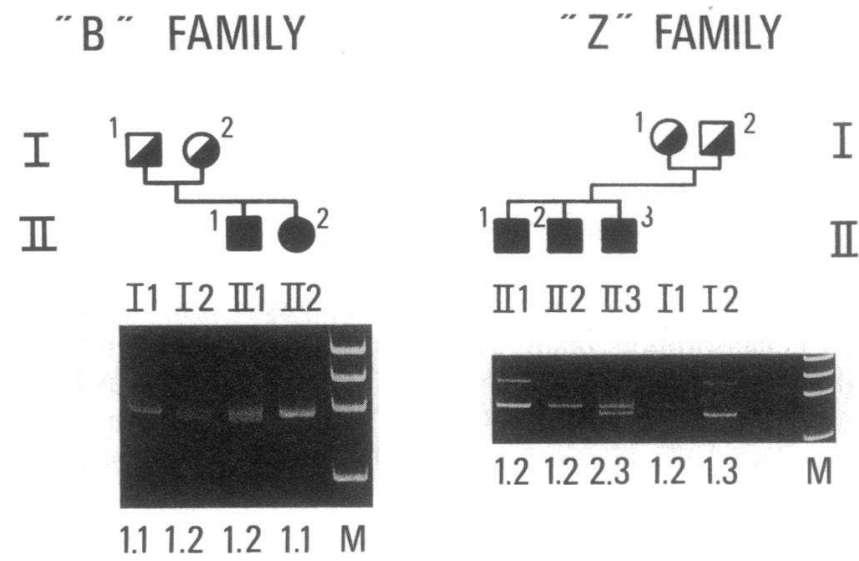

Figure 3. Genotyping with the apo-B minisatellite. PCR amplification of apo-B minisatellite was performed as follows: $1 \mu \mathrm{g}$ genomic DNA; $40 \mathrm{pmol}$ of each primer; $2.5 \mathrm{IU}$ Taq polymerase (Ampli Taq from Cetus). The reagents were used according to the manufacturer's instructions. 25 cycles were performed in a DNA thermocycler (Perkin-Elmer Cetus) as follows: $1 \mathrm{~min}$ denaturing $94^{\circ} \mathrm{C} ; 1 \mathrm{~min}$ annealing $55^{\circ} \mathrm{C} ; 1 \mathrm{~min} 30 \mathrm{~s}$ elongation $73^{\circ} \mathrm{C}$. DNA was analyzed on 4.4\% acrylamide gels. Below each track, genotypes are indicated as association of two alleles numbered 1,2 , or $3 . M$, molecular weight standards given by phage $\Phi \times 174$ DNA-HaelII digest (top to bottom $1350,1078,872,603 \mathrm{bp}$ ). 
were affected, they inherited different apo-B VNTR alleles from their mother. In family $Z$, three different alleles for the apo-B minisatellite were present: VNTR 1, 2, and 3. Parental chromosomes were easily identified in the children, revealing the transmission of different parental alleles $\left(\mathrm{II}_{1}, 1-2 ; \mathrm{II}_{2}, 1-2\right.$; and $\mathrm{II}_{3}, 2-3$ ) in each affected child. Thus, in both families, each affected child has inherited different apo-B alleles from at least one parent (Fig. 3).

\section{Discussion}

Anderson's disease was formerly defined by clinical and biochemical findings as a defect in fat transport limited to intestinal absorbing cells. It was suggested that, in these patients, the lack of postprandial chylomicronemia and apo-B48 in plasma could reflect a defective synthesis of apo-B, which is essential for formation and secretion of triglyceride-rich lipoproteins. We have previously shown (3) that this was not the case: apoB48 is present in normal or increased amounts in intestinal cells from the patients, suggesting either a defect in posttranslational apo-B48 expression, or in the intracellular assembly, or secretion of chylomicrons.

A group of Canadian children present a very similar phenotype (chylomicron retention disease) (16). In these patients, in vitro synthesis of apo-B by cultured intestinal explants was similar to those of normal controls, but the incorporation of mannose into apo-B was decreased. It seems unlikely that defective glycosylation could impair chylomicron secretion since apo-B glycosylation can be almost completely inhibited by tunicamycin in cultured rat or chicken liver cells $(17,18)$ without noticeable effect on VLDL secretion. All of these findings raise doubts about the causal role of a defect in the structure or expression of the apo-B gene in Anderson's disease.

In this study of two unrelated families with two and three affected children, respectively, we could not obtain conclusive cosegregation using seven RFLPs of the apo-B gene. This is compatible with the finding of a normal sized apo-B mRNA in the patient's intestine as well as with our previous observation (3) of increased amounts of apo-B48 in intestinal cells. Nevertheless, because of the very large size of the apo-B gene $(42 \mathrm{~kb})$ in frame point mutations not detected by DNA or mRNA blotting analysis can affect important functional areas of apo-B such as lipid binding or LDL receptor recognition domains (19).

To obtain more conclusive information on the molecular origin of this disease, we have done a linkage study between the phenotype and the polymorphism of the AT-rich minisatellite flanking the $3^{\prime}$ terminus of the apo-B gene downstream of the second polyadenylation site. This hypervariable region contains tandem repeats of a $15-\mathrm{bp}$ unit differing in number from 25 to 52. Population studies have shown as many as 15 different alleles, in 318 unrelated individuals $(20,21)$. This large allelic variation makes the apo-B VNTR locus very informative in linkage analysis.

Our results show that two affected siblings have received different alleles from their parents (family $B$ ) and that in the $Z$ family the $3^{\prime}$ VNTR alleles identified are transmitted in such a way that a phenotype linked to a defect in the apo-B gene can be formally excluded whether the transmission is dominant or recessive. The significance of the reduced levels of apo-B and apo-AIV mRNA is unclear. Apo-B mRNA has been found either increased (22) or reduced (9) in hepatic and intestinal biopsies of recessive abetalipoproteinemia patients, a disease not linked to a defective apo-B gene, in which the intestinal and hepatic secretion of apo-B-containing lipoproteins is impaired. Presumably, in Anderson's disease apo-B and apo-AIV mRNA low levels result from either feedback regulatory transcription or increased degradation.

Furthermore, besides apo-B, the plasma concentration of other apoproteins (AI, AII, C), cholesterol, phospholipids, and HDL are also greatly reduced in these patients. The new data we present exclude the apo-B gene and strongly support the view that other gene(s) encoding for other apoproteins or for intracellular proteins essential for the assembly or secretion of the lipoprotein particles should be responsible for this disease. The reason why triglyceride and apo-B VLDL produced by the liver are normal, but cholesterol and apo-B LDL are greatly reduced, remains unexplained.

\section{Acknowledgments}

We would like to express our appreciation to Drs. Aldons Lusis, Camilla Heinzmann, Gerd Assman, and Harald Funke for providing the apo-B and apo-AIV probes. We thank Dr. Philippa Talmud and Dr. James Scott for reviewing the manuscript. The excellent technical assistance of Mrs. Jacqueline Marais, Ms. Marie-Pierre Belot, and Mr. Yves Issoulié is greatly acknowledged.

\section{References}

1. Anderson, C. M., R. R. W. Townley, and J. P. Freeman. 1961. Unusual causes of steatorrhea in infancy and childhood. Med. J. Aust. 11:617-621.

2. Roy, C. C., E. Levy, P. H. R. Green, A. Sniderman, J. Letarte, J. P. Buto, J. Orquin, P. Brochu, A. M. Weber, C. L. Morin, et al. 1987. Malabsorption, hypocholesterolemia and fat-filled enterocytes with increased intestinal apoprotien-B: chylomicron retention disease. Gastroenterology. 92:390-399.

3. Bouma, M. E., I. Beucler, L. P. Aggerbeck, R. Infante, and J. Schmitz. 1986. Hypobetalipoproteinemia with accumulation of an apoprotein-B like protein in intestinal cells. Immunoenzymatic and biochemical characterization of seven cases of Anderson's disease. J. Clin. Invest. 78:398-410.

4. Biemer, J. J., and R. E. Mc Cammon. 1975. The genetic relationship of abetalipoproteinemia: a report of the occurrence of both diseases in the same family. J. Lab. Clin. Med. 85:566-565.

5. Talmud, P. J., J. K. Lloyd, D. P. R. Muller, D. R. Collins, J. Scott, and S Humphries. 1988. Genetic evidence from two families that the apolipoprotein-B gene is not involved in abetalipoproteinemia. J. Clin. Invest. 82:1803-1806.

6. Leppert, M., J. L. Breslow, L. Wu, S. Hasstedt, P. O'Connell, M. Lathrop, R. R. Williams, R. White, and J. M. Lalouel. 1988. Inference of a molecular defect of apolipoprotein-B in hpobetalipoproteinemia by linkage analysis in a large kindred. J. Clin. Invest. 82:847-851.

7. Collins, D. R., T. J. Knott, R. J. Pease, L. M. Powell, S. C. Wallis, S Robertson, C. R. Pullinger, R. W. Milne, Y. L. Marcel, S. E. Humphries, et al 1988. Truncated variants of apolipoprotein-B cause hypobetalipoproteinemia. Nucleic Acids Res. 16:8361-8375.

8. Munich, A., D. Daegelen, C. Besmond, J. Marie, J. C. Dreyfus, and A. Kahn. 1982. Cell-free translation of messenger RNAs from human muscle biopsies: a miniaturized tool for investigation of neuromuscular diseases. Pediatr. Res. 16:335-339.

9. Bouma, M. E., I. Beucler, M. Pessah, C. Heinzmann, A. J. Lusis, H. Y. Naim, T. Ducastelle, B. Leluyer, J. Schmitz, R. Infante, and L. P. Aggerbeck. 1990. Description of two different patients with abetalipoproteinemia: synthesis of a normal sized apolipoprotein-B48 in intestinal organ culture. J. Lipid Res. 31:1-16.

10. Maniatis, T., E. F. Fritsch, and J. F. Sambrook. 1982. Molecular Cloning: A Laboratory Manual. Cold Spring Harbor Laboratory, Cold Spring Harbor, NY. $545 \mathrm{pp}$.

11. Knott, T. J., R. J. Pease, L. M. Powell, S. C. Wallis, S. C. Rall, Jr., T. L. Innerarity, B. Blackhart, W. H. Taylor, Y. Marcel, R. Milne, et al. 1986. Complete protein sequence and identification of structural domains of human apolipoprotein-B. Nature (Lond.). 323:734-738.

12. Mehrabian, M., V. N. Schumaker, G. C. Fareed, R. West, D. F. Johnson, T. Kirchgessner, H. C. Lin, X. Wang, Y. Ma, E. Mendiaz, and A. J. Lusis. 1985 Human apolipoprotein-B: identification of cDNA clones and characterization of mRNA. Nucleic Acids Res. 13:6937-6953. 
13. Gunning, P., P. Ponte, H. Okayama, J. Engel, H. Blau, and L. Kedes. 1983. Isolation and characterization of full-length $\mathrm{CDNA}$ clones from human $\alpha, \beta$ and $\gamma$ actin mRNAs: skeletal but not cytoplasmic actins have an amino-terminal cysteine that is subsequently removed. Mol. Cell. Biol. 3:787-795.

14. Boerwinkle, E., W. Xiong, E. Fourest, and L. Chan. 1989. Rapid typing of tandemly repeated hypervariable loci by the polymerase chain reaction: application to the apolipoprotein-B 3 hypervariable region. Proc. Natl. Acad. Sci. USA. 86:212-216.

15. Benlian, P., C. Bonaiti, P. Douste-Blazy, and C. Junien. 1989. Candidate gene approach to type II a hypercholesterolaemia. Lancet. i:1201-1202.

16. Levy, E., Y. Marcel, R. J. Deckelbaum, R. Milne, G. Lepage, E. Seidman, M. Bendayan, and C. Roy. 1987. Intestinal apo-B synthesis, lipids and lipoproteins in chylomicron retention disease. J. Lipid Res. 28:1263-1274.

17. Bell-Quint, J., T. Forte, and P. Graham. 1981. Glycosylation of apolipoproteins by cultured rat hepatocytes: effect of tunicamycin on lipoprotein secretion. Biochem. J. 200:409-414.

18. Siuta-Mangano, P., D. R. Janero, and M. D. Lane. 1982. Association and assembly of triglyceride and phospholipid with glycosilated and unglycosilated apoproteins of very low density lipoproteins in the intact liver cell. J. Biol. Chem. 257:11463-11467.

19. Soria, L. F., E. H. Ludwig, H. R. G. Clarke, G. L. Vega, S. M. Grundy, and B. J. Mc Carthy. 1989. Association between a specific apolipoprotein-B mutation and familial defective apolipoprotein-B100. Proc. Natl. Acad. Sci. USA. 86:587591.

20. Jenner, K., A. Sidoli, M. Ball, J. R. Rodriguez, F. Pagani, G. Giudici, C. Vergani, J. Mann, F. E. Baralle, and C. Shoulders. 1988. Characterization of genetic markers in the 3 'end of the apo-B gene and their use in family and population studies. Atherosclerosis. 69:39-49.

21. Ludwig, E. H., W. Friedl, and B. J. Mc Carthy. 1989. High resolution analysis of a hypervariable region in the human apolipoprotein B gene. Am. J. Hum. Genet. 45:458-464.

22. Lackner, K. J., J. C. Monge, R. E. Gregg, J. M. Hoeg, T. J. Triche, S. W. Law, and H. B. Brewer, Jr. 1986. Analysis of the apolipoprotein B gene and messenger ribonucleic acid in abetalipoproteinemia. J. Clin. Invest. 78:17071712. 